\title{
Religious Pluralism and Christian Faith A Case for Soteriological Agnoticism
}

Catherine Cornille

\begin{abstract}
The plurality of religion is a remarkable fact of our time, leading to debates, controversies and changes in Christian theology. The main element is soteriological and ecclesiological debate as it relates to the question of the salvation of non-Christians. This implies about the redemptive value of the action of Jesus Christ and the Church need to continue that work in the world. Accordingly, we assess the relevance and understanding of the claim extra ecclesia nulla salus. This question, however, becomes an important and timely opportunity to place the dialogue between the different religious denominations. This dialogue helps to overcome prejudices and to realize the presence and action of God at work in other religions with his grace.
\end{abstract}

Keywords: Church, Jesus Christ, Plurality of Religion, Soteriology.

\section{Resumo}

A pluralidade religiosa é uma realidade marcante do nosso tempo, provocando debates, mudanças e controvérsias no âmbito teológico cristão. O principal elemento em debate é soteriológico e eclesiológico, pois diz respeito à questão da salvação dos não-cristãos. Isto implica sobre o valor redentor da ação de Jesus Cristo e a necessidade da Igreja como continuadora dessa obra no mundo. Nesse sentido, avalia-se a pertinência e a compreensão 
da afirmação extra eclesiam nulla salus. Esta questão, porém, torna-se uma fundamental e oportuna ocasião para acontecer o diálogo entre as diferentes confissões religiosas. Este diálogo ajuda a vencer preconceitos e a perceber a presença e a ação de Deus agindo nas outras religiões com a sua graça.

\section{Palavras-chave: Igreja, Jesus Cristo, Pluralismo Religioso, Soteriologia.}

\section{Introduction}

Confrontation with the reality of religious plurality has represented one of the most fundamental, and controversial theological challenges of our times. Whereas the fact of religious diversity is of course not new, it is only in the course of the past fifty years that its implications for theological relection have fully dawned on the Christian tradition. For Roman Catholic theologians, Vatican Council and in particular the publication of the document Nostra Aetate, opened the door for a more open and constructive engagement with other religions. This has given rise to the development of new theological disciplines: theology of religions, and interreligious theology or comparative theology, each with their own orientations and areas of specialization. Whereas Theology of Religions addresses the fundamental theological questions regarding the salvation of non-Christians and the implications of religious plurality for traditional theological claims regarding the uniqueness of Jesus Christ and of Christianity, Comparative Theology or Interreligious Theology engages one or more other religions more directly in dialgue on particular religious and theological themes. There has been some dispute among theologians about the relationship between these two fields of inquiry and about the degree of their mutual dependency. Comparative theologians in particular have come to question the need for a priori theological statements regarding the religious other and favor instead concrete engagement with a particular religious tradition, and the varied theological insights which this may yield.

At the heart, or at least at the origin of Christian theology of religions lies the question of the possibility of salvation of non-Christians, or the necessity of the Church for salvation. This has been a question which has preoccupied the Church - to a greater or lesser extent - since its inception. Christian reflection on the topic has come to be crystallized around Cyprian's expression "extra ecclesiam nulla salus" which, though originally directed to schismatics and heretics within the Church, became the presumed official position of the 
Church in relation to non-Christians. Its starkest formulation may be found in the Council of Florence's Decree for the Jacobites (1442), which states:

No one remaining outside the Catholic Church, not only heathens, but also Jews and heretics can enter the eternal life, but they will go to the eternal fire which was prepared by the devil and his angels, unless, before the end of their life they become part of the Church.

These negative formulations have from the very beginning prompted the development of creative theological formula to allow for the possibility of salvation before and outside the Church, from Justin Martyr's notion of the "logos spermatikos" to Thomas Aquinas' "invincible ignorance" and from the Concil of Trent's distinction between baptism "in voto" and "in re" to Karl Rahner's "anonymous Christian". All of these expressions reflect the struggle within Christian theology to maintain a balance between the Biblical emphases on the uniqueness of Jesus Christ on the one hand (John 14:6, Acts 4:12), and the universal salvific will of God on the other (1 Tim 2:4, Acts 14:17).

The remarkable fact in all of this is that there has not been any official Church teaching on whether or not other religions may be regarded as means to salvation. While the Church certainly does recognize the possibility of salvation of non-Christians, the role of their particular religion in this process has remained unspecified, even to this day. Theologians of religions have been more vocal in arguing for or against the recognition of other religions as vehicles of salvation. The various arguments in this regard have been classified in terms of the paradigms of exclusivism, inclusivism, pluralism, and more recently particularism.

There has been considerable discussion about the usefulness of these paradigms, especially as theologians have come to develop more nuanced positions and refuse to be locked within one or the other fixed position. I would like to propose not so much abandoning these paradigms, but rather limiting their reference and use to questions of the presence and status of truth in other religions. Focus on the question of non-Christian religions as means to salvation has led to various kinds of impasses, as I will attempt to demonstrate in the first part of my paper. Alternatively, I would like to argue for a position of "soteriological agnosticism" which I believe not only adheres with Church teaching, but also contains a certain logical and theological consistency. While truth and salvation are of course closely intertwined in Christian theology, I believe that it is possible and necessary to continue to reflect on the presence and the status of truth in other religions, leaving the more elusive question of their role in the salvation of non-Christians to the realm of divine mystery. 


\section{Salvation in the Exclusivist Paradigm}

Even though the adage "extra ecclesiam nulla salus" was not originally directed against non-Christians, ${ }^{1}$ it does reflect the strong Christian belief that the sacrament of baptism is necessary for salvation. This, in turn, is based on the Pauline conception of Jesus Christ as the second Adam and on the Christian anthropological notion of original sin. If faith in Christ's redemptive suffering and the baptismal rite of purification from the stain of original sin are required in order to partake in the salvific grace of God, then those who do not share this faith or this experience cannot be guaranteed salvation. While the Church may have recognized the presence of "pagan saints" outside of the Church, these individuals were regarded as saintly and saved not because but in spite of their religious traditions. The religions themselves were viewed mostly from the perspective of their depravity. This of course also reinforced the urgency of mission in the history of Christianity and the conception of mission as a saving of souls from submission to false gods and harmful ritual practices.

The strongest modern theologian to radically reject the possibility of salvation outside the Church or outside of faith in Jesus Christ is the Swiss theologian Karl Barth. Barth's rejection of other religions and of the possibility of salvation of non-Christians is not based on a radical contrasting of the teachings of other religions with those of Christianity. Barth was if fact remarkably knowledgeable about other religions and about some of the formal similarities with Christian teachings. ${ }^{2}$ The uniqueness of Christianity as vehicle of salvation is based on the unmerited grace which God had bestowed upon Christianity.

Because of this, Christianity is the only religion which can claim the status of revelation, while all other religions remain in the category of purely human searches for truth and salvation. With regard to members of other religions, Barth called for compassion and tolerance "which is informed by the fornearance of Christ, which derives therefore from the knowledge that by grace God has

\footnotetext{
${ }^{1}$ Gavin D'Costa, "Extra ecclesiam nulla salus revisited" in Religious Pluralism and Unbelief (edited by Ian Hamnett). London: Routledge, pp. 132-135. It was the refusal of bishop Novatianus to readmit lapsed Christians into the Church following the Decian persecutions which led to the possibility of schism and to the pronouncement of the axiom.

${ }^{2}$ In discussing the importance of grace for salvation, for example, he discusses analogous teachings in certain schools of the Hinduism and Buddhism, thereby manifesting more than general knowledge about those traditions. Karl Barth, Church Dogmatics 2/1 (London and New York: T \& T Clark, 1961), p. 356.
} 
reconciled to Himself godless man and his religion. It will see man carried, like an obstinate child in the arms of its mother, by what God had determined and done for his salvation in spite of his own opposition."'3 Other religions are thus regarded as a positive hindrance to the salvation of their members.

A third text which comes close to denying salvific efficacy to other religions is the Vatican document Dominus Iesus, published in 2000. While the text does recognize that "the various religious traditions contain and offer religious elements which come from God," (21) it also emphasizes the distinction between "faith" which may be found in Christianity and "belief" which characterizes the attitude of other religions (7). In borrowing this Barthian distinction, the Church thus seems to deny salvific contents to the teachings and practices of other religions. It is, however, somewhat more ambiguous in admitting on the one hand that "the followers of other religions can receive divine grace" while also insisting that "objectively speaking they are in a gravely deficient situation in comparison with those who, in the Church, have the fullness of the means of salvation." (22) Other religions are thus not regarded as means of salvation, at least not in any way analogical or complementary to the salvation offered in the Church. At best, these religions may be regarded as a "preparation for the Gospel." $(21)^{4}$ Dominus Iesus must be understood primarily as a reactionary document which takes issue with theological positions which seem to go to far in admitting the salvific efficacy of all religions, and which thus threaten to lead to relativism. The document ultimately remains vague or ambiguous with regard to the role of other religions in the salvation of their followers.

\section{Salvation in the Pluralist Paradigm}

The pluralist approach to the question of the salvation of non-Christians might be regarded as the diametrical opposite of the exclusivist position, and was developed largely in direct reaction to this position. It emphasizes the basic equivalence of all major religions as vehicles for salvation or liberation, and it thus abandons the idea, ingrained in most religions, of the superiority of any one religion. The main proponent of this position has been the

\footnotetext{
${ }^{3}$ Karl Barth, Church Dogmatics 1/2, p. 299.

${ }^{4}$ It must be noted that the notion of preparation evangelica here as evolved from its original reference by Eusebius of Caesaria to the Hebrew and Greek heritage of Christianity to include also the good that may be found in other religions.
} 
British theologian John Hick. His work is oriented mainly to debunking the traditional Christian faith in the uniqueness of Jesus Christ and the centrality of Christianity and of the Church in the history of salvation. Inspired by the Kantian distinction between phenomenon and noumenon and by the religious or mystical distinctions between the apophatic and the kataphatic approaches to God, he argues that all religions are "not necessarily competitive, in the sense that the validity of one entails the spuriousness of the others, but that they are better understood as different phenomenal experiences of the one divine noumenon, or, in another language, as different experiential transformations of the same transcendent informational input." Here, the question of the salvific efficacy of any religion is judged not on the basis of the self-understanding of any particular religion, but rather on the basis of a more generic or common criterion, i.e. the degree to which a religion is able to lead its followers from self-centeredness to Reality-centeredness. Salvation for Hick is thus marked by the overcoming of the attitude of self-centeredness. And any religion which is able to accomplish this may be regarded as salvific.

Catholic pluralist Paul Knitter approaches this question of the possibility of salvation of non-Christians and through non-Christian religions from a perspective of salvation "from below." Focusing less on the paschal than on a this-worldly conception of salvation as the establishment of the Kingdom of God in the world, he defines salvation primarily as the "well-being of humans and the earth." In this Kingdom-centered approach, other religions are regarded as salvific to the extent that they contribute to this "eco-human well-being". Knitter states that from this perspective, other religions are "not only "ways to salvation," they are, more precisely and more engagingly, "ways of the Kingdom" (viae Regni)." Other religions are thus to be regarded as "sacraments" for their followers, just as the church is a "sacrament" for Christians." The principled equality of all religions is regarded by Knitter as a necessary condition for the possibility of dialogue between religions. Like Hick, he thus attempts to reinterpret or to downplay Christian beliefs which have been the basis for its claim to uniqueness and superiority. He also believes that Christians have misinterpreted the early "one and only" references to Jesus in terms of definitive and propositional statements, rather than in terms

\footnotetext{
${ }^{5}$ God has Many Names, p. 94.

${ }^{6}$ Jesus and the Other Names, p. 19 and throughout the book.

${ }^{7}$ Jesus and the Other Names, p. 118.

${ }^{8}$ Idem.
} 
of the "love language" they were intended to express. ${ }^{9}$ Knitter thus proposes to replace the categories of "fullness, definitive and unsurpassable" which are traditionally ascribed to Jesus with the categories of "universal, decisive and indispensible," which would continue to recognize the central role of Jesus Christ not only for Christians but also for believers of other religions while also acknowledging the unique contributions of other religions to the salvation of the world.

The pluralist stance is thus characterized by a departure from any religion-specific conception of salvation in order to recognize the equality of all religions as mediators of salvation. One may argue that Paul Knitter's conception of salvation is still inspired by a Christian liberation theological notion of the Kingdom. But his approach is so deeply motivated by a concern to acknowledge the equality of all religions that the Christian inspiration and content of the notion of the Kingdom is downplayed in order to allow for the input from other religions.

\section{Salvation in the Inclusivist Paradigm}

The inclusivist approach to the question of salvation of non-Christians attempts to maintain a balance between Christian faith in the uniqueness of Jesus Christ as mediator of salvation and belief in the universal salvific will of God. It differs from the pluralist stance in so far as it emphasizes the fact that all salvation must ultimately be mediated by Christ, and from the exclusivist stance in so far as other religions are themselves seen to play a positive role in procuring salvation for their followers. While inclusivists do not state that other religions are self-sufficient ways to salvation, or mediate salvation in ways analogous to the Christian tradition, they do recognize some salvific power in their teachings and practices. Karl Rahner, who is generally identified as the original representative of this approach, argued that "it is a priori quite possible to suppose that there are supernatural, grace-filled elements in non-Christian religions." ${ }^{10} \mathrm{He}$ based this belief on the idea that human beings are essentially socially oriented, and that, if they are thought to be able to attain salvation, this would have to be mediated by the social and institutional structures through which they engage with the world and with the absolute. He therefore stated in his second thesis that "a non-Christian religion

\footnotetext{
${ }^{9}$ Jesus and the Other Names, p. 68.

${ }^{10}$ Karl Rahner, Theological Investigations, vol V. Danton and Longman \& Todd, 1966, p. 121.
} 
can be recognized as a lawful religion (although only in different degrees) without thereby denying the error and depravity contained in it."11 This belief, combined with Rahner's emphasis on the fact that all salvation comes through Christ or that Christ is the final and constitutive cause of salvation led him to suggest that Christians might regard non-Christians who are animated by the qualities of "faith, hope and love" as "anonymous Christians." 12

Whereas other inclusivist theologians tend to shy away from the latter expression, they do like Rahner recognize the possibility of salvation of non-Christians by means of, rather than in spite of their respective religious traditions, while refraining from regarding these traditions as paths to salvation equal to Christianity. The Belgian Jesuit Jacques Dupuis, for example, refers to other religions as "complementary" ways to salvation, while adding the adjective "asymmetrical" to the complementarity. Whereas he acknowledged the possibility of other saviors, and of other ways to salvation, he continues to refer to Jesus Christ as the "norma normans non normatur." ${ }^{13}$ Jesus remained for Dupuis the only human face of God. However, in so far as Christ revealed the reality of salvation as expressed through selfless love (agape), and in so far as agapeic love is certainly manifest in other religions, those religions must also be acknowledged as means to salvation. ${ }^{14}$ While the Reign of God is thus present in other religions, he believed that those religions remain "oriented to the Church as their final cause" 15 since "only in the Church is the full visibility of its complete mediation."16

Mark Heim's approach to the question of the salvation of non-Christians and the salvific roles of different religions is unique among inclusivists. Rather than considering other religions from a Christian conception of salvation, Heim suggests that each religion offers a different understanding of salvation and that the teachings and rituals of particular religions must be approached and affirmed in relation to their distinctive conceptions of salvation. Buddhist practices are thus not to be seen in light of the beatific vision, but rather as leading to an experience of salvation as ultimate liberation (nirvana) or as emptiness (sunyata). While Heim thus acknowledges the existence of

\footnotetext{
${ }^{11}$ Idem.

${ }^{12}$ Ibid., p. 131.

${ }^{13}$ Ibid., p. 294.

${ }^{14}$ Ibid., p. 323-326.

${ }^{15} \mathrm{Ibid}$, p. 348.

${ }^{16}$ Jacques Dupuis, Toward a Christian Theology of Religious Pluralism. Maryknoll: Orbis Books, 1997, p. 319
} 
many "salvations," he nonetheless affirms the superiority of the Christian understanding of salvation and the contemplation of the triune God. Arguing with Jerome Gellman that "we should prefer and account which rationally "saves" the greatest referential value for the largest number of religious experiences" $" 17$ he believes that the Christian Trinitarian conception of salvation is able to encompass most of the ends of other religions. The ultimate ends of the other religions may then be seen to represent "an intensified realization of one dimension of God's offered relation with us." "Whereas some schools of Buddhism may thus emphasize and cultivate the impersonal aspect of God, Islam approaches the ultimate end in personal and relational terms. While Christianity may learn from each of these ends, Heim also states that they can only be regarded as "penultimate at best in comparison with the Trinitarian option" ${ }^{19}$ and states that "insofar as alternative religious ends lack or rule out real dimensions of communion with the triune God, they embody some measure of what the Christian tradition regards as loss or damnation." ${ }^{20}$ As such, while Heim acknowledges different types of salvation, and the capacity of different religions to lead their adherents to particular ends, each of these ends is ultimately seen to fall short in relation to the Christian end, and non-Christians thus only have access to a partial experience of salvation, or to an experience of partial salvation.

\section{Salvation in the Particularist Paradigm}

A paradigm which has recently been added to the list of possible attitudes toward the religious other is that of "particularism." This attitude, as the term suggests, is based on a thorough awareness of the particularity of every religious tradition and their mutual incommensurability. Each religion must be regarded from within its own frame of reference and the conception of salvation of one religion cannot be translated into, let alone imposed upon another religious tradition. Within the Christian tradition, this position is generally associated with the cultural-linguistic theory of religion of George Lindbeck. For him, religious doctrines must be regarded as "communally authoritative rules of discourse, attitude and action" ${ }^{21}$ the truth of which can

\footnotetext{
${ }^{17}$ Mark Heim, The Depth of the Riches. Grand Rapids, W.B. Eerdmans, 2008, p. 41-42.

${ }^{18}$ The Depth of the Riches. Grand Rapids: Eerdmans2001, p. 179.

${ }^{19}$ Ibid, , p. 128

${ }^{20}$ Ibid., p. 162.

${ }^{21}$ The Nature of Doctrine. Religion and Theology in a Postliberal Age. Philadelphia: Westminster Press, 1984, p. 18.
} 
only be measured intrasystemically in terms of their internal coherence. ${ }^{22}$ As such, the Christian conception of salvation cannot be applied to Buddhists since it would be regarded as unintelligible and nonsensical. Each religion is thus called to resign itself to the particularity of its own conception of salvation and truth, and to refrain from subjecting other religions to their particular religious framework.

\section{Soteriological Agnosticism}

In his very thorough overview of Biblical texts, Gerald O'Collins traces the idea of the salvation of all peoples from the Old Testament, through the example and teachings of Jesus to the Acts and the letters of Paul. ${ }^{23}$ The belief that non-Christians may be saved is thus firmly established in Christian scriptures. But the role of non-Christian religions in this process of salvation remains subject to intense theological debate, as pointed out above.

While each of the models discussed advance valid theological points, none offers a fully satisfactory account of the salvific nature of other religions. The main problem is that they all overreach what can be meaningfully and logically stated from within a particular religious tradition. Exclusivism a priori rejects the salvific potential of other religions on the basis of its focus on the uniqueness of Jesus Christ and the necessity of baptism for salvation. However, in addition to the difficulty this raises with similar contents in other religions and the apparent injustice of depriving large populations and cultures from the means of salvation, it is not possible or necessary to deny any salvific potential to any religion other than Christianity. To affirm the reality of salvation through faith in Jesus Christ and the sacrament of baptism does not in fact require rejecting all other means. Whereas some religious teachings and practices may or must be condemned if they are perceived to be in contradiction with one's own teachings on and path to salvation, it is impossible to assess and therefore to reject wholesale the salvific value and components of another religion from outside of the tradition. While it may be logical from within a certain understanding of faith, it does not measure up to the broader understanding of religion and religious commitment as a reality and a commitment which can only be fully grasped or comprehended from within.

\footnotetext{
${ }^{22}$ Ibid., p. 81.

${ }^{23}$ Salvation for All God's Other Peoples. Oxford: Oxford University Press, 2008.
} 
The pluralist affirmation of the presence of salvation in and through the teachings of other religions suffers from the opposite exaggeration. Whereas other religions certainly may be vehicles of salvation, it is difficult to conceive of how someone belonging to another religion could possibly make such judgment. Pluralists tend to address or circumvent this question by defining salvation in terms of what is perceived to be a common denominator between religions (such as the shift from self-centeredness to Reality-centeredness or socio-economical and ecological well-being). However, such conceptions of salvation may be seen to remain either tied to the particular conceptions of certain religions, and/or lack the richness and depth of the conceptions of salvation developed in all of the religions. It is inconceivable that any religion will want to exchange its traditional understanding of salvation for the lowest or even the highest common denominator among religions.

The inclusivist perspectives on the question of salvation in other religions attempt to maintain a more nuanced position. While they continue to adhere to a specifically Christian understanding of salvation, they also recognize the possibility of salvation in and through other religions, albeit in a partial and derivative way. This leads to artificial and awkward theological constructions. Whatever salvation is present in other religions must from a Christian theological perspective come from Christ. But other religions are also regarded as incomplete or deficient in comparison to the Christian path to salvation. Christians will naturally judge the salvific teachings and experiences in other religions on the basis of their own understanding and experience of salvation. But in so far as these salvific elements are also seen to be tainted by error and deficiency, they cannot be affirmed as genuinely conducive to salvation, or conducive to the fullness of salvation promised in Christianity. As with the previous two paradigms, one must admit that it is impossible from the outside to judge the relative importance and "purity" of particular teachings or practices in the whole of the religious life and experience of members of a particular religion. Moreover, from within a Christian eschatological framework, partial salvation is no salvation at all. ${ }^{24}$ In order to make sense of the possibility of some degree of post-mortem salvific progress for non-Christians, the British theologian Gavin D'Costa has attempted to resurrect the Christian notion of the Limbo, which would keep open for non-Christians the possibility of

\footnotetext{
${ }^{24}$ Buddhism or Hinduism may here be in a more comfortable position in their assessment of other religions, since they may acknowledge a gradual evolution to final liberation through various lifetimes.
} 
salvation without granting them the fullness of the experience, which, per Church teachings, can only be attained through faith in Christ and baptism.

While it is logical and laudable that Christian theologians have attempted to make theological sense of the salvation of non-Christians and of their religions, I suggest placing a moratorium on this particular question and admitting a fundamental and inescapable ignorance on the question of the salvific power of other religions. Not only is it impossible to know whether the ultimate ends of different religions are the same or different, but it is also impossible to assess whether and to which extent the teachings and practices of another religion might inadvertently lead to the salvation promised within one's own religious tradition. All I can know and attest to as a Christian is the belief and experience that salvation is offered through faith in Jesus Christ and through the sacraments of the Church (in addition, of course to its ethical teachings). But I cannot judge whether a Buddhist or a Shinto may be saved through or in spite of their respective religious traditions. In this, my position is close to that of particularism which would argue that one can only speak from within one's own religious framework and that one does not have access to the internal dynamics and experience of the other religion. As a member of a particular faith community, one can only attest to the experiences and to the promises of one's own tradition.

This is also how I read the silence of documents such as Nostra Aetate on this issue. Theologians have interpreted this document as both affirming (Paul Knitter) and denying (Gavin D'Costa) the presence of salvific grace in other religions. However, the fact of the matter is that the document does not make a statement to either effect. It affirms the presence of "rays of that Truth which enlightens all men" in other religions while also proclaiming Christ "the way, the truth and the life" (John 14:6), in whom men may find the fullness of religious life, in whom God has reconciled all things to himself."(art. 2) In The Dogmatic Constitution of the Church (Lumen Gentium) Vatican II speaks of the various groups which are included in the "plan of salvation." It speaks first of all of the Jews, but also of "those who acknowledge the Creator, in the first place amongst whom are the Moslems: these profess to hold the faith of Abraham, and together with us they adore the one, merciful God, mankind's judge on the last day." (art. 16) The text further states that: 
Nor is God remote from those who in shadows and images seek the unknown God, since he gives to all men life and breath and all things (cf. Acts 17:25-28), and since the Saviour wills all men to be saved (cf. 1 Tim. 2:4). Those who, through no fault of their own, do not know the Gospel of Christ or his Church, but who nevertheless seek God with a sincere heart, and, moved by grace, try in their actions to do his will as they know it through the dictates of their conscience - those too may achieve eternal salvation.

The elements of goodness and truth in other religions are here regarded as a "preparation for the Gospel." As such, Christians are called to continue to proclaim the Gospel which contains the fullness of truth. While these documents certainly do affirm the possibility of salvation of non-Christians, it is never clearly asserted that the religions themselves offer the means to salvation, or the fullness of the means to salvation.

This vagueness, I believe, is fitting, since as a Christian one cannot affirm or deny the presence of the fullness of salvific grace in other religions. Such attitude may be regarded as arrogance, in so far as one tends to focus only on one's own religion as containing the fullness of slavific grace. However, it may also be regarded as an expression of humility, in so far as one can only state what one has experienced and what one knows, leaving assessment about the salvific status of other religions to divine judgment.

\section{Soteriological Agnosticism, Mission and Dialogue}

The attitude of agnosticism about the salvific nature of other religions in no way diminishes the importance of both mission to and dialogue with other religions. Whereas the missionary impulse might disappear within a pluralist approach, be tempered within some forms of inclusivism, and become highly restrictive from a particularist perspective, the attitude of ignorance about the efficacy of other religions in bringing their followers to salvation may generate a continuing motivation to witness to the salvific power of one's own faith. While other religions may or may not lead to salvation, mission here involves a desire to share with others what one believes to be a true way to salvation. Unlike particularism, the attitude of soteriological agnosticism remains based on a belief in the unity and the universality of truth and in the possibility of communicating that truth across religious traditions. But unlike exclusivism, it approaches other traditions with an attitude of respect arising from the 
recognition that the other religion may also possibly represent a genuine path to salvation. The very fact that one can never know, at least on this side of eternity, whether or not other religions are in effect genuine means to salvation renders the idea of testifying to the salvific power of one's own tradition all the more urgent. To be sure, members of other religions may approach Christians in exactly the same way: convinced that their own religious path leads to the ultimate end and eager to help others come to that same realization and experience. But it is in this act of mutual witnessing that dialogue takes place.

Dialogue is often thought to require an attitude of complete equality among dialogue partners. ${ }^{25}$ However, this is not only unattainable from a religious perspective, but also unnecessary for dialogue. All one needs for a genuine exchange between members of religious traditions is interest in the other and openness to the possibility of discovering elements of value and truth in the course of the exchange. The absence of a priori judgments about the slavific potency of the other religion may give way to such openness and to respect for the true alterity of the other. In addition to allowing for a more unbiased encounter with the other religion, soteriological agnosticism may also lessen the competitive assertion of the superiority of one's own tradition in regard to others. By acknowledging one's ignorance about the salvific nature and power of other religions, one may also abandon traditional hierarchical and superlative religious designations which would suggest that one's religion is "the only" or "the best" way to salvation. This, too, one cannot know. One can certainly assert with passion and conviction that one's religion offers the means to salvation, and that it represents an opportunity and a calling to all, but since there is no way to measure the salvation of other religions, there is no basis to compare and contrast it to one's own. This softening of exclusive claims to salvation and truth may also create a greater overture to dialogue on the part of both dialogue partners. For the Christian, it offers the opportunity to approach the other religion as at least a potential path to salvation. And for the dialogue partner, it may create a greater confidence in the genuine interest in the other.

The attitude of soteriological agnosticism may also serve to overcome the traditional distinctions and tensions between mission and dialogue. ${ }^{26}$

\footnotetext{
${ }^{25}$ See for example Leonard Swidler, After the Absolute: The Dialogical Future of Religious Reflection (Minneapolis: Fortress Press, 1990), p. 44; Jean Claude Basset, Le Dialogue Interreligieux (Paris: Les Editions du Cerf, 1996), p. 298; Paul Knitter, Death or Dialogue, (London: SCM press, 1990), p. 32. ${ }^{26}$ For more on the plea to overcome the distinction between mission and dialogue, see my The Im-Possibility of Interreligious Dialogue. (New York: Crossroads, 2008) , pp. 69 ff.
} 
Whereas dialogue is often regarded as a form of informational exchange and as a means to mutual understanding and tolerance, mission involves witnessing to the truth of one's own tradition and attempting to bring others to that truth. Soteriological agnosticism allows one to approach the other religion with a genuinely open an inquisitive attitude, rather than with set ideas about its potential for salvation. It also engenders a sense of respect for the teachings and practices of the other as - at least possibly - means of salvation. As such, mission may be conducted with openness to the potential truth of the other religion, while communication of the fullness to the salvific truth of one's own religion can only take place through the witness of one's life and testimony.

The abandonment of a priori statements about the salvific nature of other religions may also help to resolve the theological debates about the necessity and the priority of theology of religions in relation to comparative theology. Some comparative theologians, James Fredericks in particular, have come to reject the discipline of theology of religions and the traditional paradigms mentioned above as legitimate and useful ways of dealing with religious plurality from within the Christian tradition. ${ }^{27}$ Rather than approach other religions from the perspective of general theological presuppositions about their salvific value, they suggest delving into the actual engagement with the teachings and texts of the other religion in order to assess in each case of dialogue or comparative theology whether and what one may be able to learn from the other religion. The attitude of soteriological agnosticism in the theology of religion may serve to address these concerns. However, while theology of religion may abandon or bracket the question of the salvific nature of other religions, it cannot absolve itself from reflecting on the possible presence of truth in other religions.

\section{Soteriological agnosticism and Truth in Dialogue}

While it is impossible to assess the salvific nature of other religions in general, or of any other religion in particular, it is possible and even necessary for theology to entertain the question of whether there might be elements of truth in other religions and how those might relate to one's own religious truth claims. Such questions are always at play, either implicitly or explicitly, in one's engagement with other religions. Even the rejection by some comparative

\footnotetext{
${ }^{27}$ James L. Fredericks, Faith among Faiths. Christian Theology and Non-Christian Religions. New York: Paulist Press, 1999.
} 
theologians of blanket statements about the truth of other religions in general in favor of a focus on particular religions and dialogues involves some theological presupposition about the possible presence of truth in other religions.

Whereas truth and salvation are closely intertwined in the Christian tradition, the notion and the contents of truth are more tangible and subject to change and growth than the reality of salvation. Though Christians believe in Jesus Christ as the embodiment of truth, the understanding and the elaboration of this truth is believed to be an endless process in which "the Church is always advancing toward the plenitude of divine truth, until eventually the words of God are fulfilled in her" (Dei Verbum, 8). Theologians are thus invited to be open to various sources of divine truth and revelation and to reflect on their meaning and status in relation to the truth of Christianity.

The second Vatican Council in fact marks a significant change in the doctrine of the Catholic Church with regard to the presence of truth in other religions. Whereas Church documents of and since Vatican II remain silent on the question of salvation of non-Christian religions, they do explicitly acknowledge the presence of "Truth which enlightens all men" in the teachings and practices of other religions. (Nostra Aetate 2, Lumen Gentium 16, Ad Gentes 15, Dialogue and Proclamation 29, Dominus Iesus 2, 8, 21). The texts also emphasize that these truths are often mixed with error and that they are not to be regarded as equivalent to the fullness of truth which is to be found in Christianity. But, as Francis Sullivan also points out, this is a major departure from prior Church teaching. ${ }^{28}$ Whereas the idea of the presence of God's word in the tradition of the people of Israel was already acknowledged by Church Fathers as Iraeneus in terms of "praeparatio evengelicae," the extension of this principle to apply to even non-theistic religions is genuinely new. It has opened the door for the possibility of dialogue with other religions and for the development of disciplines such as interreligious theology or comparative theology.

Comparative theology is a relatively new area of theology which focuses on studying another religious tradition in such depth and detail that it sheds new light on one's own religious tradition. It may thus be regarded in short as the practice of theology, or "faith seeking understanding" within the horizon of religious diversity. The ultimate goal of comparative theology is thus not merely advancing the understanding of the other religion (although that is a necessary

\footnotetext{
${ }^{28}$ Whereas the idea of the presence of God's word in the tradition of the people of Israel was already acknowledged by Church Fathers as Iraeneus in terms of "praeparatio evengelicae," the extension of this principle to apply to even non-theistic religions is genuinely new.
} 
requirement for comparative theology), but advancing the understanding and the truth of one's own religion. This may take place through the practice of juxtaposing homologous texts, teachings or practices in the two traditions in order to come to a sharper understanding of the particularity and the meaning of one's own tradition. By placing texts and teachings within a broader interpretive horizon, certain teachings may indeed catch new meanings, at times by the power of contrast, and at times by way of similarity and placement alongside other analogous teachings. Comparative theology, however, may do more than confirming the truth of one's own teachings through contrast or analogy with another religion. It may also enlarge Christian self-understanding through the introduction of new symbols, ritual practices or frameworks of interpretation. Just as religions have continuously and implicitly borrowed from one another in the course of history, so comparative theology offers an opportunity for religions to engage one another more intentionally and openly in order to explore what different religions might learn from one another. The possibility and limits of such learning, however, depends on the understanding and the status of truth granted to other religions. And this is precisely the purview of the discipline of Theology of Religions.

\section{Paradigms of Truth in Theology of Religions}

While the question of the salvation of other religions may be a theological enigma or oxymoron, theology of religions certainly has the right and the responsibility to reflect on the question whether there is truth to be found in other religions and what the status of that truth might be. The way in which theologians come to terms with this question continues to mark the distinction between the different paradigms in the theology of religions, and points to their continued usefulness or convenience in indicating the possibility and limits of engaging other religions in dialogue and in the exercise of comparative theology.

If the question of truth becomes the basis for distinguishing attitudes toward other religions then the different paradigms would be characterized in terms of a rejection of the presence of any truth in other religions (exclusivism) and the recognition of the presence of truth in other religions (inclusivism and pluralism). The difference between the latter two paradigms is based on whether one's own religion is regarded as the norm and criterion for discerning truth in other religions (inclusivism) and whether it is not (pluralism). 
While exclusivism is based on the denial of any truth outside of one's own tradition, it may still generate some interest in other religions, if only as a way to put into sharper relief the contrast between the truth of one's own religion and the ignorance of the other. The attitude of exclusivism is based on religious presuppositions which tend to be immune to factual refutation. Even the presence in the other religion of certain teachings identical to one's own is not accepted as a counter-argument since the truth of the teachings of the other religion are regarded as tainted by the general ignorance of the whole of the other teaching tradition. The attitude of particularism, though based on epistemological rather than theological presuppositions, in fact rejoins exclusivism with regard to the question of the presence of relevant truth in other religious traditions. While it does not as such deny the possible presence of truth in other religions, it denies the possibility for Christians to know, let along to judge their truth. With regard to the dialogue with other religions, its implications are the same: dialogue will not yield any significant theological development or growth.

Pluralism, on the contrary, is based on the assumption that all religions contain elements of truth and that no religion should be subject to the truthclaims of other religious traditions. In matters of truth, all religions are thus seen to be on an equal playing field. While in some cases this leads to complete relativism in matters of truth (what is true for me may not be true for you), in other cases certain generic criteria of truth may be advanced, based on what one perceives to be a common de nominator among religions or else based on one's personal taste: the degree to which religions help to liberate individuals from social and economic oppression, the degree to which it fosters gender equality, the degree to which it respects the dignity of all life, etc. This probably represents the way in which many individuals approach dialogue from outside of any established religious institution or context. It allows individuals to pick and choose from among the teachings of different religions on the basis of their own taste and judgment and without accountability or reference to a pre-existing or ulterior conception of truth. This points to the tension between pluralism and traditional religious approaches to the religious other. Every religion is based on a particular understanding of the truth of their own teachings which they naturally regard as normative for their engagement with other religious traditions.

The attitude of inclusivism recognizes elements of truth in other religions while also adhering to the truth claims of one's own tradition as the ultimate 
criterion to discern such truth. It is based on an essentially religious notion of truth as revealed and anterior to or beyond purely personal judgment and discrimination. Here, believers approach the other in dialogue from a presupposition of the truth of their own religious teachings and from the normativity of such teachings with regard to the truth of the other religion. This normativity may be adopted in the form of a conviction about the superiority of one's own truth, or from a more humble view that this is all one does and can know about ultimate truth, or from a combination of these two approaches to truth. The belief in the superiority of one's own religious truth claims is certainly in line with the self-understanding of most religious traditions. It reflects an a priori epistemic confidence which is necessary to bring about total surrender and commitment in followers. However, it becomes fragile or vulnerable when confronted with the fact of religious plurality and the reality of competing truth claims. On what grounds does one argue the superiority of one's own truth in relation to those of other religions?

A more coherent approach to the normativity of one's own religious claims to truth may thus start from a humble recognition that one cannot but approach the truth of other religions but from one's own faith in the truth of one's own religion. This does not imply any degree of relativism, since, as far as one knows, this truth is indeed reflective of the way things are or ought to be. But it does soften the notion of normativity by recognizing the element of faith included in all claims to religious truth and the fact that others approach the truth of one's own tradition similarly from a faith in the (superior) truth of their own teachings.

Inclusivism still allows for different approaches toward the normativity of one's own and the truth of other religions. It may give way to a maximal conception of one's own normativity and truth which recognizes truth in the other religion only in so far as it corresponds with teachings or practices which are already part of the deposit of truth of one's own religion. In this type of "closed" inclusivism, dialogue becomes a form of recognizing and affirming teachings one already holds, and adjusting or reinterpreting teachings of other religions to fit one's established religious understanding. It tends to lead to a domestication of the truth of the other religion, thus limiting the possibility of growth through dialogue with the truth of other religions.

However, inclusivism may also approach the truth of the other from the perspective of a minimal approach to the normativity of one's own truth. 
This "open" inclusivism implies that any teachings or practices which are not in contradiction with one's own truth might possibly be true. It allows for recognition of truth not only in teachings which are similar to or the same as one's own, but also in new and different teachings. The Vatican II document Nostra Aetate actually suggests this much when it states that there may be truth even in "teachings which, though differing in many respects from the ones she holds and sets forth, nonetheless often reflect a ray of that Truth which enlightens all men" (art. 2, my italics). It is the emphasis of this document on the presence of truth in difference which opens the door for Christians to learn from other religions in dialogue.

The categories "inclusivism, exclusivism, inclusivism, and particularism" thus represent a convenient and necessary classification of religious attitudes toward the truth of other religions in relation to one's own. They may be applied to any religious tradition and they provide a religious grounding for and an indication of the contours, the possibilities and the limits of any particular dialogue. To be sure, in the course of the dialogue, certain presuppositions about the truth of other religions may change. However, any inquiry into the truth of the other is already inspired by one or the other religious presupposition. Rather than abandon the paradigms altogether, as some have suggested, I would thus argue for a more perspicacious use of them.

\section{Conclusion}

Christian theological views on the salvific role of non-Christian religions, from the expression "extra ecclesiam nulla salus" to the present day paradigms in the theology of religions are based on the firm belief that there is indeed salvation inside the Church, offered through the sacraments, in particular baptism, and through the life of faith and grace mediated by the Church. This positive assertion or experience has quite understandably led to various judgments, positive, negative and nuanced, on other religions as means of salvation. However, I have tried to demonstrate that commitment to one's own religion as means of salvation does not require, or even allow for either positive or negative judgment of the salvific nature of other religions. As Christians we may certainly hope or believe that God uses other religions to impart saving grace to its followers. But theological judgments on this matter overreach what can be known or asserted from within a Christian perspective. 
Leaving aside the question of the salvation of non-Christians, theologians are still called to reflect on the reasons for and the way of engaging other religions in dialogue. This is why reflection on the question of the presence and the status of truth in other religions continues to be vital, and why the classical paradigms in theology of religion continue to be valid and useful. They determine the contours of the dialogue and suggest the degree of theological change and growth possible as a result of such a dialogue. Such focus on the question of truth in theology of religions would render more evident the mutual dependency between Theology of Religions and Comparative Theology. And it would relieve theologians from the necessity of developing awkward theological constructions to account for the possibility of salvation in non-Christian religions.

\section{References}

BARTH, Karl, Church Dogmatics 2/1. London and New York: T \& T Clark, 1961.

BASSET, Jean Claude, Le Dialogue Interreligieux. Paris: Les Editions du Cerf, 1996.

CORNILLE, Catherine, The Im-Possibility of Interreligious Dialogue. New York: Crossroads, 2008.

D'COSTA, Gavin, "Extra ecclesiam nulla salus revisited" in Religious Pluralism and Unbelief. London: Routledge.

DUPUIS, Jacques, Toward a Christian Theology of Religious Pluralism. Maryknoll: FREDERICKS, James L., Faith among Faiths. Christian Theology and Non-Christian Religions. New York: Paulist Press, 1999.

HEIM, Mark, The Depth of the Riches: A Trinitarian Theology of Religious Ends. Michigan and Cambridge: William B. Eerdmans Publishing Company, 2008.

HICK, John, God has Many Names. Louisville: Westminster John Knox Press, 1982. KNITTER, Paul, Death or Dialogue. London: SCM press, 1990.

, Jesus and the Other Names: Christian Mission and Global Responsibility. New York: Orbis Books, 1996.

LINDBECK, George, The Nature of Doctrine. Religion and Theology in a Postliberal Age. Philadelphia: Westminster Press, 1984. 
O'COLLINS, Gerald, Salvation for All God's Other Peoples. Oxford: Oxford University Press, 2008.

RAHNER, Karl, Theological Investigations, vol V. Danton and Longman \& Todd, 1966.

SWIDLER, Leonard, After the Absolute: The Dialogical Future of Religious Reflection Minneapolis: Fortress Press, 1990.

\section{Catherine Cornille}

Ph.D. em Estudos Religiosos, KU Leuven, Bélgica MA em religiões asiáticas, Universidade do Havaí BA em Filosofia, KU Leuven, Bélgica Licenciatura em Teologia, KU Leuven, Bélgica

Artigo Recebido em 06/09/2011 Artigo Aprovado em 07/11/2011 